\title{
Iceberg Scour Investigations and Sedimentology of the Southeast Baffin Island Continental Shelf
}

\author{
C.P.G. PEREIRA, ${ }^{1}$ C.M.T. WOODWORTH-LYNAS ${ }^{2}$ and J.V. BARRIE ${ }^{1,2}$
}

(Received 9 July 1986; accepted in revised form 26 April 1988)

\begin{abstract}
High-resolution sidescan imagery of the southeast Baffin Island continental margin illustrates a typical high-latitude shelf, extensively and deeply scored by the southward drift of icebergs. Evidence for iceberg scouring on the shallower inner shelf is not clearly manifested, reflecting the very thin sediment cover overlying the bedrock. On the deeper mid- and outer shelves, the iceberg scours are generally much more clearly defined. These deeper water scours, which are kilometres long, up to $90 \mathrm{~m}$ wide and $4.4 \mathrm{~m}$ deep, are not a recent occurrence. Instead they are relict and probably predate the Holocene/latest Pleistocene, when sea levels were relatively much lower.

Two depth-related surficial sedimentary environments (an inner shelf and a mid- and outer shelf environment) are recognized in the survey area. A thin ( $f e w$ centimetres thick) covering of coarse sand and/or gravel with negligible amounts of silt and clay dominate the inner shelf down to about the $220 \mathrm{~m}$ contour, and because of this sparse covering, the underlying bedrock is very often exposed. The mid-and outer shelves, which have a sediment cover up to $7 \mathrm{~m}$ thick, are texturally very variable. This variable texture reflects the effects of scouring iceberg keels in dislodging sediment and the subsequent displacement and redistribution of sediment. Underwater photographs of current generated bedforms suggest further bottom current redistribution of displaced scoured sediments and concurrent active sediment transport on the outer continental shelf.
\end{abstract}

Key words: Baffin Island continental shelf, marine geology, sedimentology, iceberg scours

RÉSUMÉ. Des images de la plate-forme continentale du sud-est de l'île de Baffin, obtenues par balayage latéral à haute résolution, révèlent un plateau typique de cette haute latitude, avec de nombreuses et profondes entailles creusées par les icebergs dérivant avec les courants en direction du sud. Les traces laissées par le raclage des icebergs sur le plateau continental près de la côte et peu profond, ne sont pas très apparentes, ce qui témoigne de l'extrême minceur de la couche de sédiments sur l'assise rocheuse. Sur le plateau intermédiaire et sur celui au large plus profonds, les sillons creusés par les icebergs sont en général bien visibles. Ces sillons en eau profonde, qui mesurent plusieurs kilomètres de long et jusqu'à $90 \mathrm{~m}$ de large et $4,4 \mathrm{~m}$ de profondeur, ne sont pas un phénomène récent mais un résidu d'érosion et ils sont probablement antérieurs à l'holocène ou à la dernière partie du pléistocène, alors que le niveau des mers était relativement beaucoup plus bas.

Dans la zone d'étude, on a distingué deux environnements dont les sédiments de surface ont un rapport avec la profondeur: un environnement de plateau près de la côte et un autre de plateaux intermédiaire et au large. Sur le plateau près de la côte, jusqu'à une profondeur d'environ $220 \mathrm{~m}$, prédomine une couche mince (quelques centimètres) de sable grossier ou de gravier contenant des quantités négligeables de limon et d'argile. Vu l'extrême minceur de cette couche, l'assise rocheuse est très souvent exposée. Les sédiments qui se trouvent sur le plateau intermédiaire et sur celui au large, et dont l'épaisseur peut atteindre $7 \mathrm{~m}$, ont une texture très variable. Celle-ci témoigne des effets du raclage des quilles des icebergs qui délogent les sédiments, ainsi que du déplacement et de la redistribution qui s'ensuivent. Des photographies sous-marines de la topographie due aux courants suggèrent que les courants de fond donnent lieu à une redistribution supplémentaire des sédiments enlevés par raclage et simultanément, au transport actif de sédiments vers la plate-forme continentale au large.

Mots clés: plate-forme continentale de l'île de Baffin, géologie marine, sédimentologie, sillons creusés par les icebergs

Traduit pour le journal par Nésida Loyer.

\section{INTRODUCTION}

Iceberg scouring of the seabed was first postulated by Darwin (1855) but attracted very little attention until the discovery of substantial hydrocarbon plays in the North Sea and off Canada's east and arctic coasts. Recent research detailing the physical attributes of iceberg scours and describing the effects of iceberg scouring on the continental shelf sediments commenced with the work of Belderson et al. (1973) in the Northeast Atlantic and Norwegian Trench areas and Harris (1974) and Harris and Jollymore (1974) off the east coast of Canada. The latter authors also recorded deep-water iceberg scours in water depths exceeding $350 \mathrm{~m}$. Current research activity into iceberg scouring and sedimentology of iceberg-scoured shelves on the Norwegian continental margin has been summarized by Lien (1983), who presented data on deep-sea scours down to a water depth of 500 $\mathrm{m}$. Lien (1983) estimated that most of the deep-water scours off Norway were made during the period between 10-11 000 and 13000 B.P.

Scouring of the seabed by iceberg keels significantly alters both the "normal" depositional pattern of sediments and their physical and textural properties. Sediment below the scouring keel is impacted upon and consequently becomes overconsolidated; sediment ploughed out in front of the advancing keel forms berms (= lateral embankments), while a small amount is put into suspension and rapidly dispersed by bottom currents (see McLaren, 1982). A section of this paper details the surficial geomorphological relief of the ice-scoured outer continental shelf, as determined from two approximately $100 \mathrm{~m}$ long underwater camera transects.

The east coast of Canada is seasonally dominated by drifting icebergs, many of which gouge out deep scours on the continental shelves on their transit south to eventual complete melting in the warmer waters of the northerly flowing Gulf Stream. Recent environmental marine geology surveys on the southeast Baffin Island shelf unequivocally indicate that the seabed has been extensively scoured by iceberg keels at a present water depth of $350 \mathrm{~m}$ and deeper (Geonautics, 1980a,b, 1981; Barrie et al., 1982). The discovery of these deep-water scours raises the question regarding the time of their formation and the effects of iceberg scouring on sediment distribution. Evaluation of the seismic data by Geonautics (1980b:29) suggest that the iceberg

\footnotetext{
${ }^{1}$ Department of Earth Sciences, Centre for Earth Resources Research, Memorial University of Newfoundland, St. John's, Newfoundland, Canada A1B $3 X 7$

${ }^{2}$ C-CORE, Memorial University of Newfoundland, St. John's, Newfoundland, Canada A1B 3X5

(c) The Arctic Institute of North America
} 
scouring seen at these depths had occurred within the recent past and not later than 100 years ago (Guigné et al., 1985).

This paper presents data on the subsurface geology, the seabed geomorphology of a scoured terrain, the iceberg scours and the effects of iceberg scouring on the surface sedimentology of the seabed. More complete discussions on relative ages of iceberg scours and the microstratigraphical and microfaunal analyses are available as technical reports (Woodworth-Lynas, 1983b; Pereira et al., 1984).

\section{DATA COLLECTION AND METHODS}

In an attempt to examine the questions posed above and further expand on the knowledge of marine geology of the southeast Baffin Island continental shelf (e.g., Lewis et al., 1979), a multidisciplinary marine survey was undertaken south- east of Baffin Island (Fig. 1) from CSS Hudson (Survey No. HU81-045).

Two hundred line kilometres of sidescan sonar imagery were collected at water depths between 190 and $350 \mathrm{~m}$. This data was collected using the Bedford Institute of Oceanography (BIO) $70 \mathrm{kHz}$ medium-range sidescan sonar system with a variable slant range between $350 \mathrm{~m}$ and $750 \mathrm{~m}$, for a total swath width of between 700 and $1500 \mathrm{~m}$. In addition to the sidescan data, geophysical seismic data were obtained using a Huntec highresolution Deep Tow System (DTS). Positions were fixed at 5 min intervals using Bionav, which is an integrated system utilizing Loran $\mathrm{C}$ and satellite navigation plus $\log$ and gyro (Wells and Grant, 1981). At these high latitudes the system is considered accurate to within $200 \mathrm{~m}$.

Water depth at the sampling stations varied between 80 and $400 \mathrm{~m}$ (Fig. 1). Ten sediment grab samples, along with three gravity cores and two piston cores, were collected. The seabed

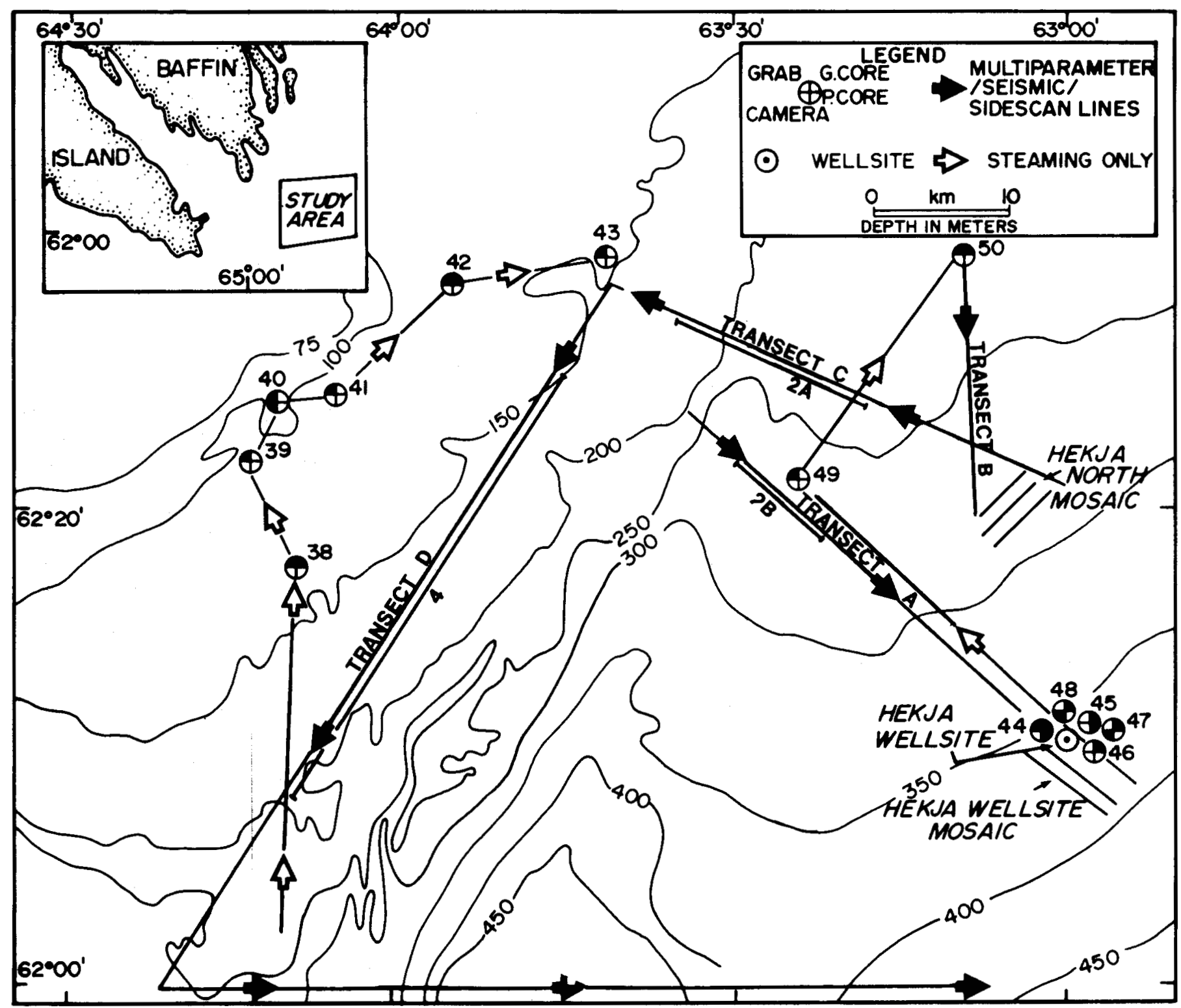

FIG. 1. Index map illustrating the bathymetry, sediment grab and core stations, camera transects, the seismic survey lines, Hekja 0-71 exploration wellsite of Canterra Energy Ltd. and the sidescan sonar study areas of Hekja North and Hekja wellsite. Geophysical transects illustrated in Figure 2 are along transects A and C, as indicated. 
sampling program was undertaken using Leheigh and Benthos gravity corers, a piston corer and a Van Veen grab. Stereo underwater camera photographs were used to document short (approx. $100 \mathrm{~m}$ ) drift transects of the seabed.

Sediment samples were analyzed following the procedural guidelines of Folk (1980). Sand size analysis was done using a Sedimentation Tower and the silt and clay analyses were done using the pipette method. Statistical parameters were calculated using the method of moments. The data are presented in Tables 1 and 2 .

\section{OCEANOGRAPHIC ENVIRONMENT}

The southeast Baffin Island shelf is dominated by the southwardflowing Baffin Current. Surface velocities of up to $30 \mathrm{~cm} \cdot \mathrm{s}^{-1}$ have been reported by LeBlond et al. (1981) for the outer shelf area; much stronger surficial currents up to $100 \mathrm{~cm} \cdot \mathrm{s}^{-1}$ have been reported for the general shelf area by Praeg et al. (1986). At the survey site seabed tidal current velocities reach a maximum velocity of $40 \mathrm{~cm} \cdot \mathrm{s}^{-1}$ and a mean of about $12 \mathrm{~cm} \cdot \mathrm{s}^{-1}$ (Dobrocky Seatech, 1982). Similar mean subsurface current velocities have been reported for the southward-flowing Baffin Current, south of the survey site and east of Hudson Strait at $400 \mathrm{~m}$ water depth (U.S. Naval Oceanographic Office, 1965:30-31).

The maximum and mean near seabed current velocities recorded at the Hekja wellsite (Fig. 1) are sufficient to generate bedforms such as ripples (see Amos and King, 1984:Table 11). The sediment ripples at the Hekja wellsite are illustrated in Figures $6 \mathrm{e}$ and $6 \mathrm{f}$, and have wavelengths $<.5 \mathrm{~m}$. Sediments in the Hekja area range from sandy silt to a mixture of silt, clay and

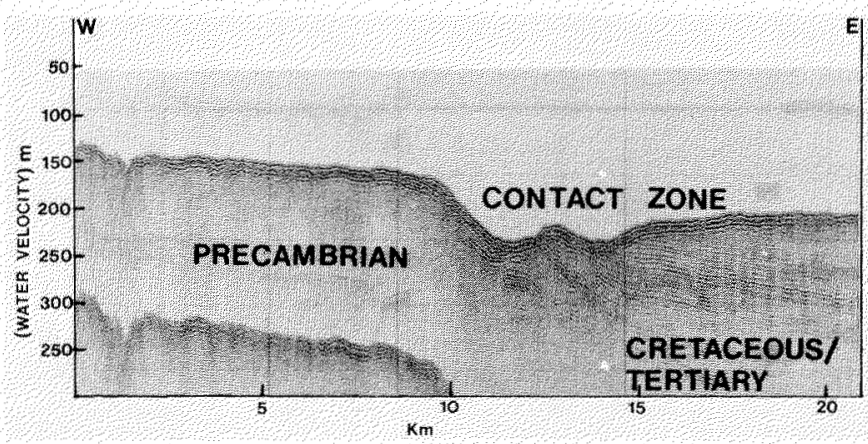

FIG. 2. Seismic reflection profiles of traverses across the Tertiary/Precambrian contact. Profile locations are illustrated in Figure 1. A: Contact zone is clearly indicated but is eroded on either side to leave a small hillock at the contact (Transect C). surficial gravel. The intermittent rippled nature of the sea floor suggests local variation between cohesionless sediment (with ripples) to predominantly cohesive sediment (without ripples).

\section{SHALLOW BEDROCK GEOLOGY}

Seismic transects A and C (Figs. 2a,b) clearly illustrate the nature of the contact between the Precambrian metamorphic basement bedrock, marginal to the coast (Jackson and Taylor, 1972), and the Tertiary bedrock, southeast of Baffin Island. The linear extent and direction of this contact zone had earlier been ascertained by Grant (1975) and described by MacLean et al., (1982) as a fault contact. The Tertiary strata to the east of the contact zone are well stratified and thicken seawards (Fig. 3), with a shallow dip to the southeast.

The hill-like feature observed immediately adjacent to the contact zone on Figure $2 \mathrm{~b}$ has been described as a mud volcano by Woodworth-Lynas (1983a). Tightly spaced seismic transects across this feature suggest it is cone-shaped and that a crater located near the crest of the cone may be a vent (WoodworthLynas, 1983a). While similar hill-like features were observed on adjacent transects across the contact zone (e.g., Fig. 2a), none of them appears to have geomorphological or seismic characteristics similar to those observed at the site of the mud volcano. A more complete discussion of the subject of mud volcanoes can be found in Woodworth-Lynas (1983a).

Seismic transect D traverses Precambrian bedrock and shows a number of well-defined northwest-southeast-trending shallow depressions in the shelf bedrock (Fig. 4). Comparison of these features with bathymetric charts for this area (Geonautics, 1980a)

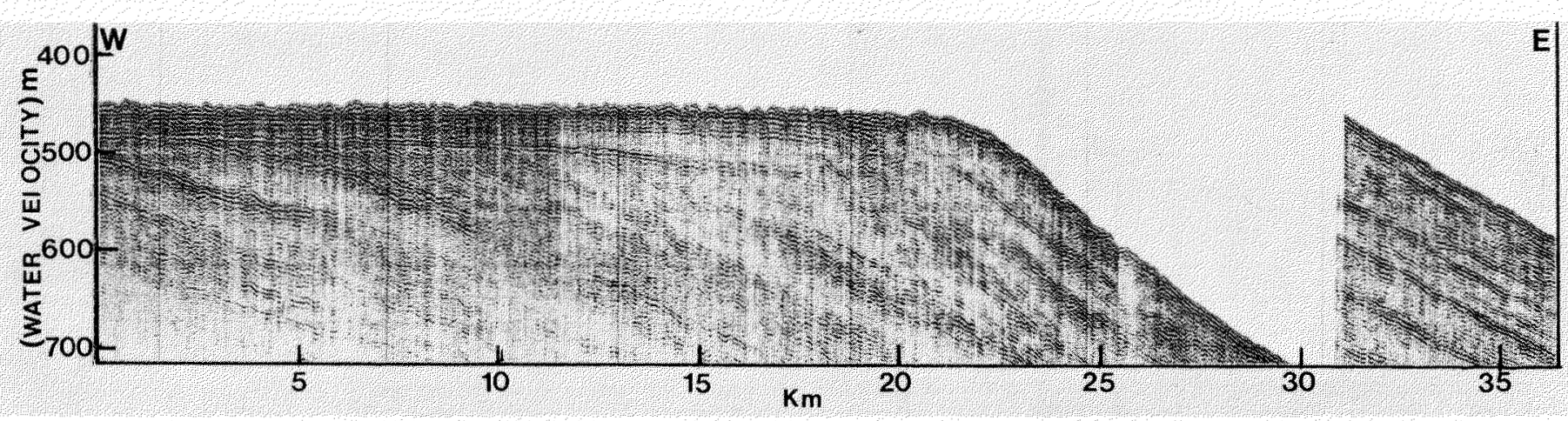

FIG. 3. Sediment overburden thickens seaward with a pronounced thickening at the continental shelf edge (multiparameter transect at $62^{\circ} \mathrm{N}$ ). 


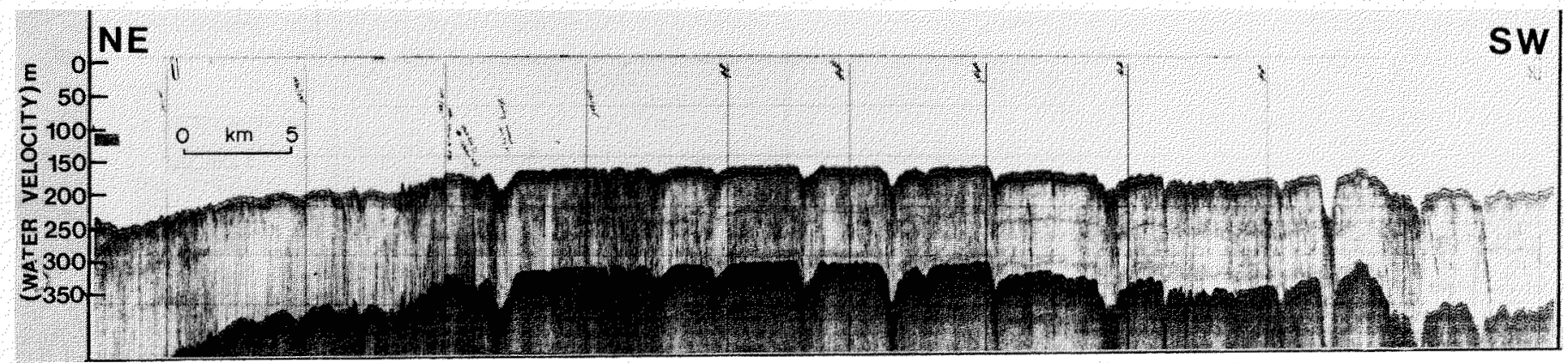

FIG. 4. Seismic reflection profile over the shallow Precambrian bedrock illustrating shallow depressions, some of which are probably fault related in origin. Profile location is illustrated in Figure 1 (Transect D).

suggests that these shallow depressions may represent subsidiary erosional channels (possibly of glacial outwash origin) to the main channel earlier described by McMillan (1973) that parallels part of the coastline. While a glacial outwash origin for some of these smaller channels is conceivable, at least one and probably more are fault-related in origin (Fig. 4); these subsidiary channels have been subsequently deepened and enlarged by glacial erosion. Subaerial erosion may also have played a part, since the shelf strata were extensively bevelled by erosion subsequent to the early Eocene (MacLean, BIO, pers. comm. 1986).

\section{SURFICIAL GEOMORPHOLOGY}

The inner continental shelf, shallower than $220 \mathrm{~m}$, has a low relief, a slightly undulose character (which is bedrock controlled) and bears little or no clear evidence of iceberg scouring. The deeper mid- and outer continental shelf down to $400 \mathrm{~m}$ has a relatively hummocky relief and is extensively scoured by iceberg keels (Figs. 5 and 7). In these deeper water areas seabed relief varies between 1 and $7 \mathrm{~m}$ (Praeg, 1982) and is apparently controlled by scouring of the seabed by iceberg keels. Microtopographic relief on the seabed is evidenced by current ripple bedforms (Fig. 6e,f). Larger, probably current-related, bedforms (megaripples) are also observed within the troughs of the iceberg scours. (An enlargement of Figure 7 possessed by the authors illustrates the bedforms.)

In general, iceberg scours identified on the outer shelf are kilometres long, as wide as $90 \mathrm{~m}$ (Fig. 7) and with scour troughs

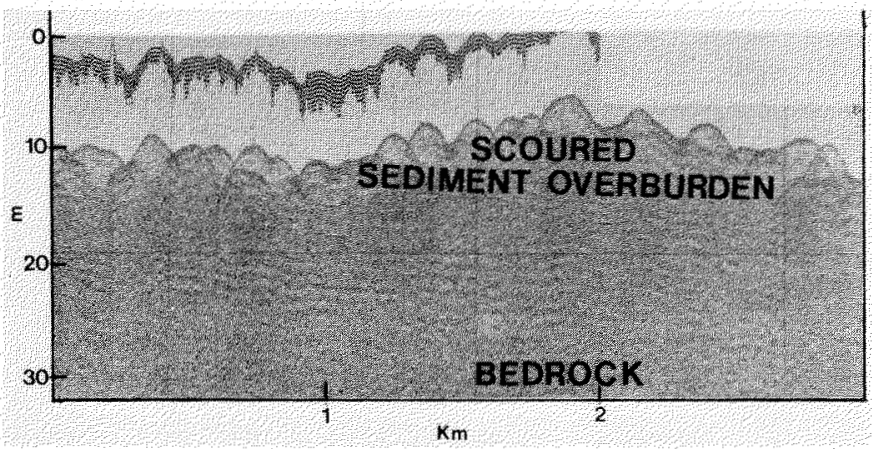

FIG. 5. Huntec DTS profiles illustrating the intensely iceberg-scoured seabed and the variable thickness of the sediment overburden in the mid-continental shelf region. Maximum depths of scours $4.4 \mathrm{~m}$ (Transect A). up to $4.4 \mathrm{~m}$ deep (Fig. 5). In the shallower (225-275 m) mid-shelf region at the Hekja North site (Fig. 1) scours have sharper profiles and a mean scour depth of $1.3 \mathrm{~m}$, whereas scours from the deeper waters $(275-365 \mathrm{~m})$ have subdued, muted profiles and a mean scour depth of $1.1 \mathrm{~m}$. This observation of deep-water scours having shallower troughs than shallow-water scours is in marked contrast to the normal relationship of deeper scour
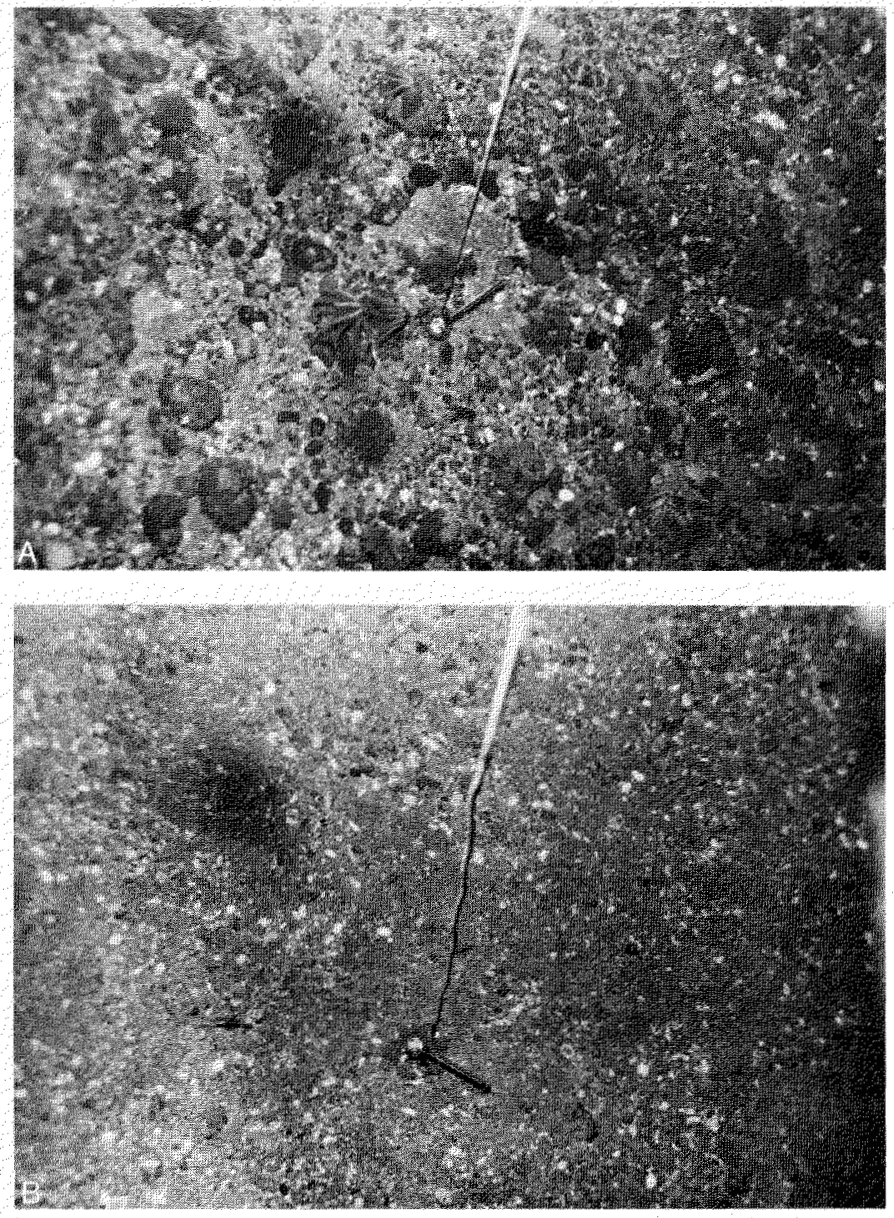

FIG. 6. Underwater photographs illustrating the different seabed sediments on the southeast Baffin Island shelf. Scale (applying to all six photographs): the camera trigger is $30 \mathrm{~cm}$ long. A, B. Photographs at $100 \mathrm{~m}$ illustrate shallow inner shelf environment of shell debris, large clasts and probable bedrock exposures (Station 40). 

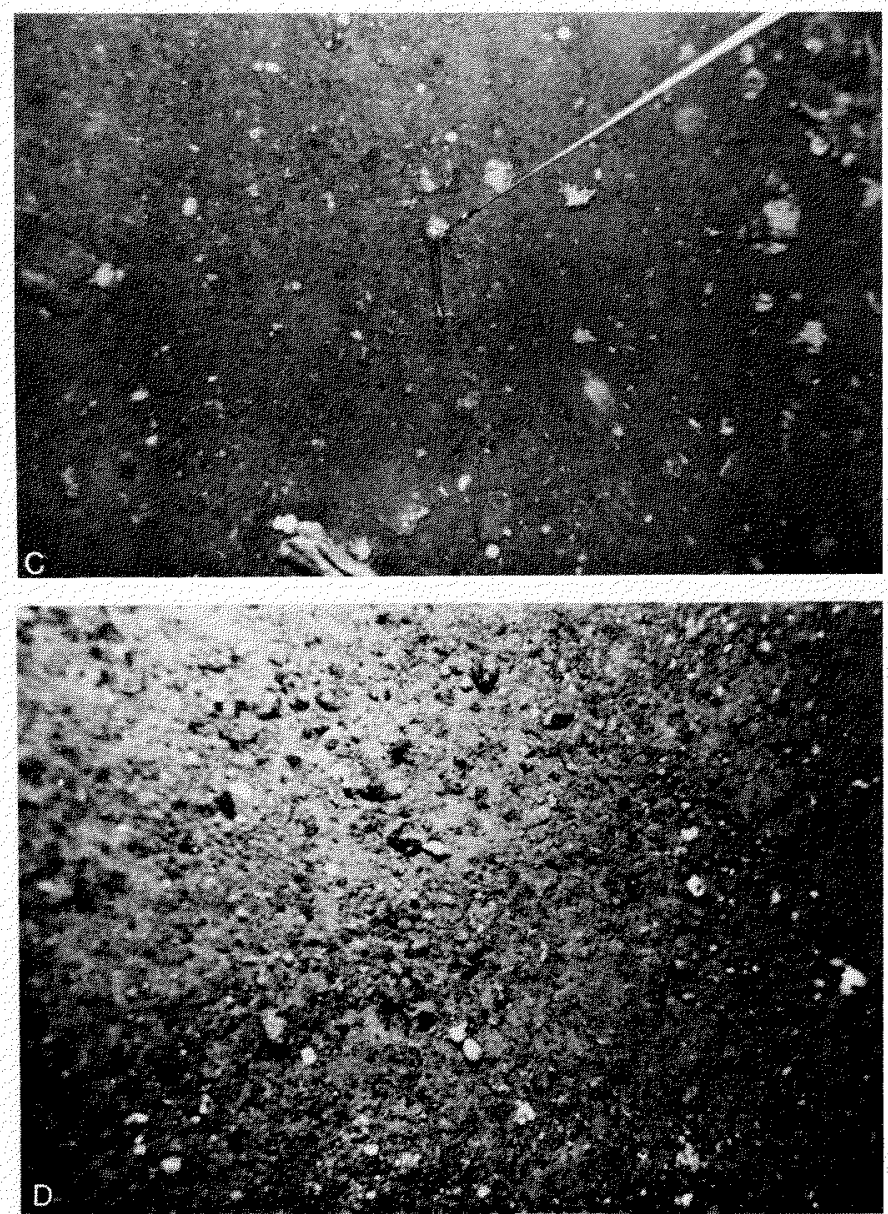

FIG. 6C, D. Photographs at $350 \mathrm{~m}$ illustrate the outer, deeper water shelf environment of a gravel- and debris-laden surface overlying a predominantly muddy sediment (Stations 47 and 48).

troughs in deeper water (see Barrie, 1980; Lewis, 1978). The subdued, muted scour profiles observed at the outer shelf Hekja wellsite area (Fig. 1) may probably be attributed to a number of factors, e.g., differential rates of scour degradation, soil strength, preferential sediment infill, etc. MacLean (1985) reports the presence of well-defined scour troughs with scour relief between 1 and $7 \mathrm{~m}$ at a water depth exceeding $500 \mathrm{~m}$ for the southeastern shelf, which reinforces the contention of Barrie (1980) and Lewis (1978); hence the deeper scour troughs observed at the shallower mid-shelf Hekja North site (Fig. 1) may be an isolated instance, perhaps reflecting slower infill due to stiffer cohesive sediments, or on the other hand they may be related to the geological time period in which this particular incidence of iceberg scouring occurred. However, additional iceberg scour data need to be analyzed from a variety of continental margin areas before the relationship between scour depth and water depth is satisfactorily resolved.

On the inner shelf, widespread iceberg scouring has not been clearly recorded for water depths shallower than $220 \mathrm{~m}$ (Pereira et al., 1984). This apparent scarcity of iceberg scours may either be an artifact related to the absence of sufficient sediment cover required to effectively record scouring by icebergs or it may be due to the actual lack of icebergs scouring the inner shelf zone. Robe et al. (1980) tracked four icebergs across the southeastern shelf of Baffin Island, and their data clearly indicate that fre-
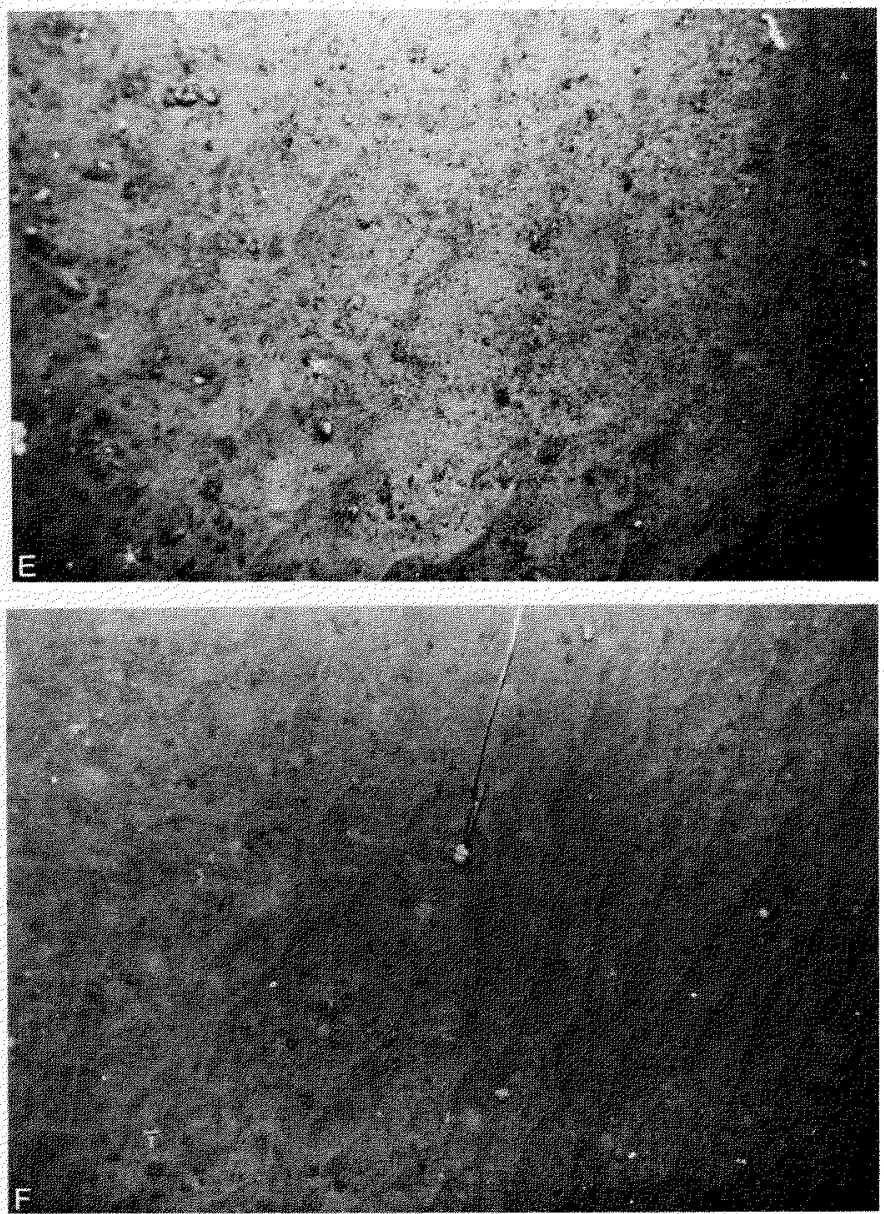

FIG. 6E. F. Photographs at the Hekja wellsite $(350 \mathrm{~m})$ illustrate current-generated ripple bedforms indicating a dynamic seabed (Stations 47 and 48).

quent groundings of icebergs do occur on the inner shelf shallower than $220 \mathrm{~m}$. Their results further show that the icebergs ground frequently, occupying nearly $40 \%$ of the observed time (138-202 days' survey time). These icebergs, which had draughts between 140 and $200 \mathrm{~m}$, were either intermittently grounded (and hence probably scouring the seabed) or firmly grounded, forming pits (see Barrie et al., 1985). Ebbesmeyer et al. (1980) estimated that an average of 3500 icebergs cross the latitudes of the study area every year, and although iceberg movements were concentrated in the core of the Baffin Current, which flows along the continental slope (Marko et al., 1982), a significant number of the icebergs were apparently grounding on the continental margins shallower than about $240 \mathrm{~m}$. Thus the absence of iceberg scour tracks on the sidescan records from the shallower shelf areas does indeed indicate it is an artifact caused by the very thin (if any) sediment cover on the inner shelf zone.

\section{SCOUR AGES}

The absolute age of scours in the survey area is not known. However, microfaunal and sedimentological studies of short cores have led to the recognition of probable buried scour surfaces (Pereira, 1984). Dating of these buried scour surfaces is somewhat problematic due to the lack of sufficient carbonate shell material. However, it is likely that the scours are all relict, since icebergs with draughts of $350 \mathrm{~m}$ or greater have not been 


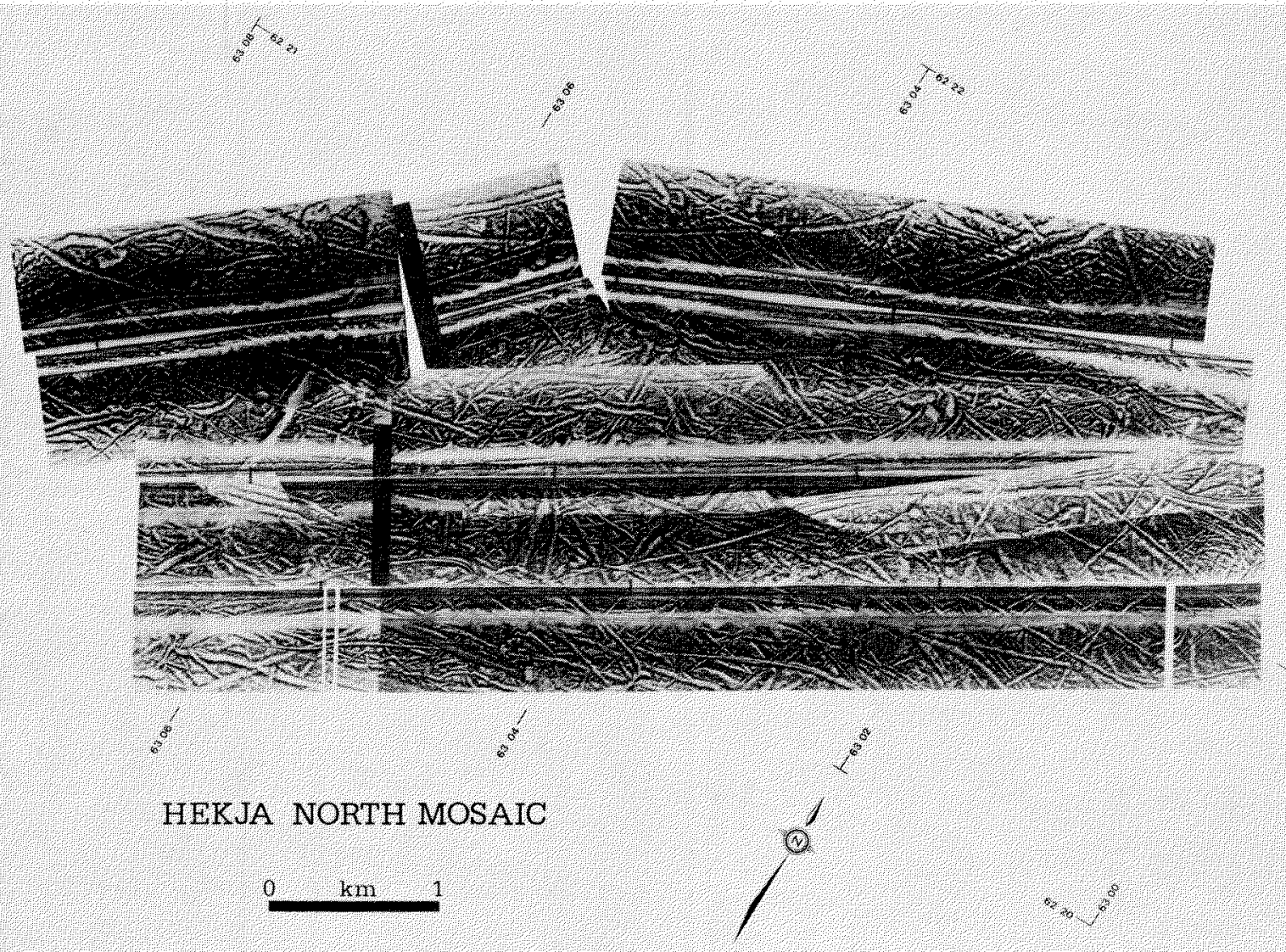

FIG. 7. Sidescan sonar mosaic of the Hekja North survey area. The seabed is completely scoured by iceberg keels. Maximum width of the scours is $90 \mathrm{~m}$. Water depth ranges from $265 \mathrm{~m}$ in the north to about $285 \mathrm{~m}$ in the south.

documented this far south. Studies by Hotzel and Miller (1983) and Robe et al. (1980) suggest that very few icebergs with draughts in excess of $230 \mathrm{~m}$ occur in these high northern latitudes, although there appears to be historical but undocumented evidence for their occurrence this far south by Fabricius in about 1780 (see Dillon, 1965). Woodworth-Lynas (1983b) determined the relative ages of the iceberg scours in the Hekja wellsite area and in the adjacent Hekja North area (Fig. 1) using cross-cutting relationships of scours developed from sidescan mosaics (e.g., Fig. 7). Essentially, this means the oldest scours are cut by younger scours but do not cut any others, and the youngest scours are those that cut older scours but are not cut by others. Scours of intermediate age will cut older scours and will also be cut by younger scours. Cross-cutting relationship results from Hekja North indicate that maximum scour width has decreased through time. Woodworth-Lynas (1983b) used this conclusion to suggest that iceberg size has decreased through time (see also Hotzel and Miller, 1983) and proposed that large icebergs may have been introduced from nearby calving ice margins in previous glacial times rather than from the present calving margins off western Greenland and the Canadian Arctic. Lowering of relative sea level by about $80 \mathrm{~m}$ (relative to glacial deposits on Baffin Island) during the last ice age (Andrews, 1980) could produce the same effects by restricting the icebergs to deeper waters farther offshore. Since lowered sea levels characterized the late Foxe (= late Wisconsinan) glaciation (Andrews, 1980), it is possible that the scours from the Hekja North area are coincident, since water depths during the early Holocene at the Hekja North site would probably have been much lower. While this may explain the occurrence and ages of scours that occur in waters shallower than $300 \mathrm{~m}$, it is not an effective tool when explaining the occurrence and ages of iceberg scours that occur in water depths exceeding $500 \mathrm{~m}$, as recorded by MacLean (1985).

\section{SEDIMENTS AND SEDIMENTARY ENVIRONMENTS}

Prior to the work of MacLean (1985) and Praeg et al. (1986), the shelf sediments were described based primarily on geophysical interpretation. Regional geophysical evidence suggests that the unconsolidated Quaternary sediment cover for the mid- and outer shelf area is ubiquitous (Grant, 1975). On the shallower Precambrian basement inner shelf area, Huntec profiles indicate negligible sediment overburden. This is indirectly supported further by sidescan imagery of the inner shelf, where evidence for iceberg scouring is rare, but where Robe et al . (1980) and Marko et al. (1982) have observed numerous grounded icebergs. This apparent lack of evidence in terms of iceberg scour tracks occurs because of insufficient sediment cover to record the grounding and scouring of drifting icebergs. In addition, where sediment cover is thin, scour relief is low and muted. These observations of little to no sediment cover on the inner shelf have been confirmed by MacLean (BIO, pers. comm. 1984), who suggests that over the entire shallow shelf area the bedrock surface may be at or very close to the surface. Farther offshore, on the outer shelf toward the Hekja North and Hekja wellsite areas, sediment overburden thickens and has a variable thickness of about $7 \mathrm{~m}$ (Fig. 5), increasing with water depth to a maximum thickness of $50 \mathrm{~m}$ at the shelf break (Fig. 3). 


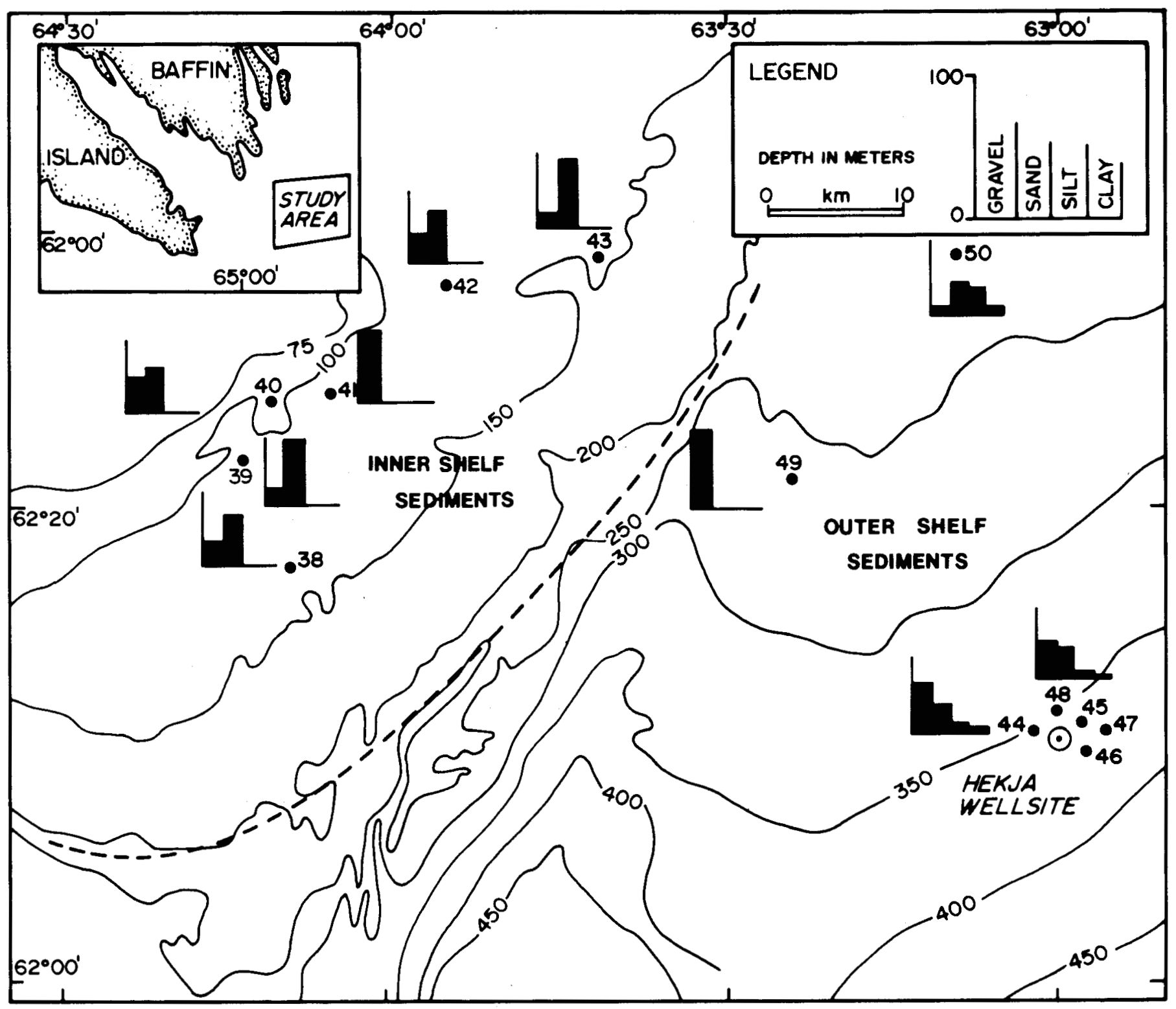

FIG. 8. Textural distribution of the surficial sediment on the inner and mid-continental shelf southeast of Baffin Island.

Geonautics (1980a) defined three sedimentary geomorphic units. The three units consist of nearshore, intermediate and deep-water environments. The nearshore unit describes an area of irregular topography and is considered to be a zone of net sediment accumulation. The intermediate unit from the $150 \mathrm{~m}$ to the $220 \mathrm{~m}$ contour describes an area of very rough topography with an apparent lack of any significant sediment cover, except within topographic lows. The deep-water environment from the $220 \mathrm{~m}$ to the $400 \mathrm{~m}$ contour has a relatively regular topography and a significant sediment cover. Earlier regional sedimentological and mineralogical studies of the shelf by Kranck (1964) and Marlowe (1968) describe essentially two depth-related sedimentary facies, an inshore and an offshore facies. Cores and sediment grab samples examined in this study, along with underwater photographic transects, clearly suggest that sediment cover in the inner shelf zone is sparse (Fig. 6a,b); coring within the topographic lows (Geonautics, 1980a, intermediate facies) was unsuccessful, suggesting that sediment cover is also thin and sparse. Hence the two Geonautics' units are combined and are equivalent to the inner shelf facies described herein. The sediment characteristics of the outer shelf/deep water units of the two studies (Geonautics and this study) remain essentially the same.

The inner shelf environment (Fig. 8) is restricted to water depths shallower than $220 \mathrm{~m}$ and is similar to the informally known Resolution Island lag facies described by Praeg et al. (1986). Texturally, this area appears to be dominated by either coarse sand or gravel with negligible amounts of silt and clay. The sediment cover is very thin and sparse. Further, photographs of the seabed clearly indicate an area dominated by large cobbles and boulders (or exposed bedrock surface) and coarse broken shell fragments (Figs. 6a,b). The epifauna consists of echinoderms and a sparse population of worm casts, but no bioturbating in-fauna were seen in any of the photographs.

The outer shelf environment (Fig. 8) describes the southeast section of the survey area from about $220 \mathrm{~m}$ down to the Hekja 
TABLE 1. Textural analysis of sediments from the southeast Baffin Island Shelf (in \%)

\begin{tabular}{cccccc}
\hline \hline Station number & Depth $(\mathrm{m})$ & Gravel & Sand & Silt & Clay \\
\hline 38 & 137 & 32.96 & 67.07 & - & - \\
39 & 115 & 14.72 & 85.28 & - & - \\
40 & 82 & 46.27 & 53.73 & - & - \\
42 & 133 & 35.07 & 64.93 & - & - \\
43 & 155 & 13.22 & 86.78 & - & - \\
47 & 397 & 49.89 & 46.11 & 2.41 & 1.58 \\
49 & 256 & 100. & - & - & - \\
50 & 265 & 6.97 & 54.65 & 35.90 & 2.49 \\
\hline \hline
\end{tabular}

wellsite. (Although only one grab sample was obtained between 150 and $220 \mathrm{~m}$ [Geonautics intermediate facies], it has been included in the inner shelf facies; however, further detailed sampling may define a transitionary sedimentary environment dissimilar to either the inner shelf or outer shelf sedimentary environment.) Texturally, the outer shelf varies considerably (Tables 1 and 2; Figs. 6c-f) from areas with little gravel to areas almost entirely of gravel, through to areas with a 50:50 mix of sand and gravel. The varying occurrence of gravel is partially a function of iceberg scouring, whereby the scour berms have had fine sediments removed by current winnowing, leaving linear lag gravel deposits similar to those seen by Josenhans and Barrie (1982) on the Labrador Shelf. Seabed photographs reinforce the surficial sediment textural analysis in that they show (Figs. 6c, d) immediately adjacent areas having markedly contrasting sedimentary textures (Table 1), e.g., one area is covered by fine sand, silt and scattered pebbles, and the other has a ubiquitous cover of pebbles. Randomly distributed across the seabed are small $(\mathrm{ca} .5 \mathrm{~cm})$ to large $(30-60 \mathrm{~cm})$ pebbles and boulders. These larger lithic fragments are probably iceberg-rafted detritus = IRD (dropstones) dropped from melting icebergs. Most of the larger detritus (boulders) are partially encrusted by algae, indicative of lengthy exposure to colonization, and hence residence, on the seabed.

Piston cores collected from the outer shelf close to the Hekja wellsite (Fig. 1) were X-rayed (Fig. 9). They show a subsurface sediment dominated by amorphous layers of fine sand and silt. Gravel is randomly scattered throughout the cores, along with larger, rarer pebbles and biogenic clasts. In contrast to the relatively high concentrations of pebbles that can be observed amidst a sandy/silty matrix on the seabed surface (Fig. 6d), pebble concentration is very low in the subsurface sediment (Fig. 9). Although pebble and boulder concentrations on the seabed at these high latitudes may have more than one origin (see Josenhans and Barrie, 1982), pebbles occurring within the subsurface sediment at the survey site are invariably matrix supported, suggesting an ice-rafted origin.

Bioclastic carbonate fragments, which occur in abundance on the inner shelf, are not very common on the outer, deeper shelf. Weak laminations seen in the X-radiographs in the lower part of the core suggest rapid alternations of sediment input from nearby sources. Bioturbation is not evident from the X-radiographs. However, surficial bioturbation occurs by surface sediment grazers, as is evident in underwater camera photographs.

\section{Grain Size Statistics}

Various techniques have been developed to interpret grain size distributions (e.g., Blatt et al., 1980; Folk, 1980; Visher, 1969; Bagnold and Barndoff-Nielsen, 1980), and care is required

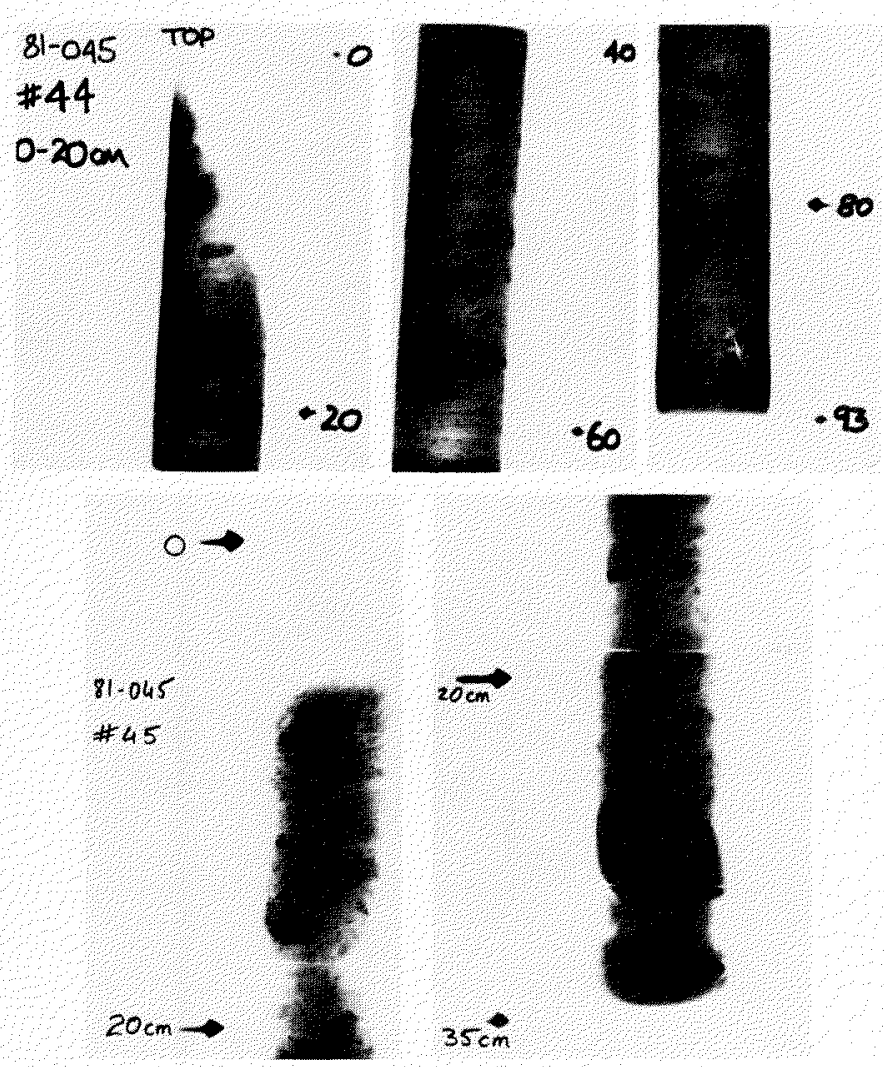

FIG. 9. X-radiographs of core sections from the Hekja wellsite survey area showing the random distribution of coarse gravel and pebble fragments along the core length. Note large cobble in core 45 . Pebbles of similar size are a common occurrence in other cores collected from the mid-shelf continental area.

when making quantitative comparisons between size distributions. Essentially, the grain size distribution of sediments is primarily the function of two independent factors - i.e., the size range of the available material and the amount of current energy that affects the sediment. The grain size and sorting characteristics of the surface sediment grab samples are presented in Table 2.

TABLE 2. Grain size sorting characteristics of sediments from the southeast Baffin Island shelf (by the Methods of Moments)

\begin{tabular}{cccccc}
\hline \hline Station number & Depth $(\mathrm{m})$ & $\mathrm{M}_{2}$ & $\mathrm{I}$ & $\mathrm{Sk}_{\mathrm{l}}$ & $\mathrm{K}_{\mathrm{g}}$ \\
\hline 38 & 137 & 0.410 & 0.761 & -1.164 & 4.329 \\
39 & 115 & 0.459 & 1.071 & -0.688 & 2.908 \\
40 & 82 & 0.465 & 0.679 & -0.627 & 5.664 \\
42 & 133 & 0.522 & 0.731 & -0.368 & 4.979 \\
43 & 155 & 0.580 & 0.750 & +0.647 & 4.855 \\
44 & 365 & 0.267 & 1.789 & +2.171 & 7.294 \\
47 & 397 & 0.312 & 1.598 & +1.755 & 7.91 \\
49 & 256 & - & - & - & - \\
50 & 265 & 0.101 & 2.539 & +0.498 & 1.975 \\
\hline \hline
\end{tabular}

The sediments from the shallower inner shelf have distinct bimodal distribution, which becomes less well defined toward the deeper mid-shelf area. The bimodal distribution indicates two sources for the inner shelf surface sediments. Sediment composition is primarily an admixture of clean, coarse to mediumgrained quartz sand and bioclastic shell debris, which explains 
the bimodal sorting characteristics for these samples. A similar bimodality is also seen in some of the deeper water silts (Table 2 ), with the modal points lying in the sand and silt fraction respectively. However, the reasons for the latter bimodality in the outer shelf are not well understood but may be explained in terms of the continuous reworking of sediments (which had been previously gouged out by scouring icebergs), current action and an unknown input of IRD sediment.

The standard deviation, which reflects the consistency in the energy level around the sediment, varies from 0.761 (moderately sorted) in the shallower water to 2.539 (poorly sorted) at the Hekja wellsite. The trend, which is well marked, probably reflects the better sorting efficiency of oscillatory wave-based currents in the shallower shelf areas. The dynamic velocities of the seabed currents (Dobrocky Seatech, 1982) that exist within the Hekja wellsite, which are strong enough to generate moderate bedforms, are perhaps not sufficient to sort the sediment efficiently and hence may explain the sediment bimodality distribution seen in the results. In addition, sediments in the deeper waters are reworked, relict sediments continuously supplemented by sediment (IRD) from icebergs; hence the poor sorting is reflected by the continuous input of fresh sediment along with the scoured, reworked sediment.

The skewness denotes the symmetry of the grain size frequency distribution. Symmetrical curves possess zero value, those with excess fine material show a positive ratio, and those with excess coarse material have a negative value. In the study area there is a gradual increase in the skewness value downslope, which indicates a relative increase of fine-grained material. The only samples with negative skewness values are from the stations shallower than $100 \mathrm{~m}$.

In summary, sediments on the continental shelf become finer downslope between 75 and $400 \mathrm{~m}$ but are more poorly sorted.

\section{SUMMARY CONCLUSIONS}

1. A series of northwest-southeast-trending shallow depressions in the inner shelf bedrock are probably subsidiary channels feeding into the main channel that parallels the coastline. While a glacial outwash origin for some of these smaller channels is conceivable, at least one and probably more are fault-related in origin and have been subsequently deepened and enlarged by glacial erosion.

2. Sidescan sonar imagery of the continental shelf indicates that iceberg scouring has extensively and deeply scored the midand outer shelves, but not the inner shelf. Data from Robe $e t a l$. (1980) and Marko et al. (1982) clearly indicate that iceberg grounding (and hence scouring of the seabed) on the inner shelf shallower than $220 \mathrm{~m}$ is common, but because of either a total lack of or insufficient sediment cover, the scour tracks have a very low relief, and this low scour relief is insufficient to show up on the sidescan images. Photographs of the seabed also illustrate an inner shelf environment virtually devoid of any substantial sediment cover.

3. Relative sea levels fluctuated throughout the late Quaternary (Andrews, 1980), and during the late Foxe, sea levels are estimated to have been lowered by about $80 \mathrm{~m}$ with reference to glacial deposits on Baffin Island. The absolute ages of iceberg scours that occur on the deeper continental shelf are not known but are believed to be considerably older than the estimate of 100 years put forward by Geonautics (1980b) and by Guigné et al. (1985). A lowered sea level during the late Foxe/early Holocene would permit icebergs of present-day draughts to scour the Hekja North area, and it is also further possible that during the same discrete time interval larger icebergs (from nearby calving margins) scoured the deeper Hekja wellsite area. The different scour reliefs recorded for the shallower Hekja North and deeper Hekja wellsite could probably be explained in terms of different soil properties, differential scour infill (by cohesion or cohesionless soils) and a dynamic current regime transporting sediment into the scours. Alternatively, iceberg scouring at the two sites could also have occurred at different time intervals prior to the Holocene.

4. Sediment analysis and underwater camera transects define two distinct sedimentary environments for the area of study. The inner shelf environment is generally a thin veneer of bioclastic shell hash and clastic quartz; photographs illustrate an environment dominated by large cobbles and boulders and some epifauna. The "clean" look of the sediment suggests that the current regime is strong and is effective in winnowing away fine sediment. The outer shelf facies, located in the deeper outer shelf zones, appears to have a surficially variable sediment texture. The texture of this surficial sediment varies across the shelf from areas of little to almost $100 \%$ gravel, to areas with an even mix of sand and gravel. This textural variation may be an artifact of iceberg scouring wherein the gravel component reflects scour berm and the even mix of sand and gravel reflects the scour trough facies plus the effect of winnowing by sea bottom currents.

5. Sedimentary ripple bedforms are quite common in the deeper shelf. Seabed current velocities, which reach a maximum of $40 \mathrm{~cm} \cdot \mathrm{s}^{-1}$, generate sediment ripples of wavelengths $<.5$ $m$ in areas where the sediment is a medium to fine sandy silt.

\section{ACKNOWLEDGEMENTS}

The authors acknowledge the assistance of $\mathrm{H}$. Westergard, of Canterra Energy Ltd., Calgary, who actively encouraged the research program. The authors thank C.F.M. Lewis, the technical staff of the Atlantic Geoscience Centre and Captain Mauger and crew of CSS Hudson during the survey. N. Fagan is thanked for her meticulous typing of the various drafts of this paper. D.J.W. Piper, B. MacLean, R.T. Gillespie and $W$. Collins reviewed earlier drafts of this report. The research was supported by a generous grant from Canterra Energy Ltd. of Calgary.

\section{REFERENCES}

AMOS, C.L., and KING, E.L. 1984. Bedforms of the Canadian eastern seaboard: a comparison with global occurrences. Marine Geology 57:167-208.

ANDREWS, J.T. 1980. Progress in relative sea level and ice sheet reconstructions, Baffin Island, N.W.T. for the last 125,000 years. In: Morner, N-A., ed. Earth Rheology, Isostasy and Eustasy. Chichester: John Wiley and Sons Ltd. 175-200.

BAGNOLD, R.A., and BARNDOFF-NIELSEN, O, 1980. The pattern of natural size distributions. Sedimentology 27:199-207.

BARRIE, J.V. 1980. Iceberg-seabed interaction (Northern Labrador Sea). Annals of Glaciology 1:71-76.

, WOODWORTH-LYNAS, C.M.T., and PEREIRA, C.P.G. 1982. Data report of the Hekja Wellsite Marine Survey undertaken during CSS Hudson Cruise No. HU81-045, October, 1981. C-CORE Data Report No. 82-2. $48 \mathrm{p}$.

BARRIE, J.V., COLLINS, W.T., and PARROTT, D.R. 1985. Grand Banks pits; description and postulated origin. Proceedings, Ice scour Workshop, Calgary, Alberta, 4-6 February 1985.

BELDERSON, R.H., KENYON, N.H., and WILSON, J.B. 1973. Iceberg plough marks in the Northwest Atlantic. Palaeogeography, Palaeoclimatology, Palaeoecology 13:215-224.

BLATT, H., MIDDLETON, G., and MURRAY, R. 1980. Origin of Sedimentary Rocks. Englewood Cliffs, New Jersey: Prentice-Hall. 782 p. 
DARWIN, C.R. 1855. On the power of icebergs to make rectlinear, uniformlydirected grooves across a submarine undulatory surface. London, Edinburgh, and Dublin Philosophical Magazine and Journal of Science 10:96-98.

DILLON, R.H. 1965. Otto Fabricius' "On the floating ice in the northern waters and particularly in the Straight of Davis." Geographical Review 45(3):405-415.

DOBROCKY SEATECH LTD. 1982. Current meter analysis in the Davis Strait. Report to Canterra Energy Ltd. Calgary, Alberta. Available at CanadaNewfoundland Offshore Petroleum Board, 140 Water Street, St. John's, Newfoundland, Canada A1C $6 \mathrm{H} 6$.

EBBESMEYER, C.E., OKUBU, A., and HELSETH, J.M. 1980. Description of iceberg probability between Baffin Bay and the Grand Banks using a stochastic model. Deep Sea Research 27A:975-986.

FOLK, R.L. 1980. Petrology of Sedimentary Rocks. Austin, Texas: Hemphill Publishing Co. $184 \mathrm{p}$.

GEONAUTICS LTD. 1980a. Seabed morphology of the southeast Baffin Island Shelf. Report to Aquitaine Company of Canada Ltd. 9 p. Available at Canada-Newfoundland Offshore Petroleum Board, 140 Water Street, St. John's, Newfoundland, Canada AlC 6H6.

1980b. Sidescan sonar survey, Hekja wellsite and vicinity. Report to Aquitaine Company of Canada Ltd. 39 p. Available at Canada-Newfoundland Offshore Petroleum Board, 140 Water Street, St. John's, Newfoundland, Canada A1C 6H6.

1981. Mosaic iceberg scouring, Davis Strait - Hekja 0-71. Report to Aquitaine Company of Canada Ltd. 6 p. Available at Canada-Newfoundland Offshore Petroleum Board, 140 Water Street, St. John's, Newfoundland, Canada A1C 6H6.

GRANT, A.C. 1975. Geophysical results from the continental margin off Southern Baffin Island. In: Yorath, C.J., Parker, E.R., and Glass, D.J., eds. Canada's Continental Margins and Offshore Petroleum Exploration. Canadian Society of Petroleum Geologists, Memoir 4:411-432.

GUIGNÉ, J.Y., ROSS, D.I., and WESTERGARD, H. 1985. Review of deep water scours in the Davis Strait and its relevance to present day activity. In: Pilkington, R., ed. Workshop on Ice Scouring, 1982. NRC Technical Memorandum No. 136:155-167.

HARRIS, I. McK. 1974. Iceberg marks on the Labrador Shelf. In: Offshore Geology of Eastern Canada. Geological Survey of Canada, Paper 24-30:97-101. and JOLLYMORE, P.G. 1974. Iceberg furrow marks on the continental shelf northeast of Belle Isle, Newfoundland. Canadian Journal of Earth Sciences 11(1):43-52.

HOTZEL, I.S., and MILLER, J.D. 1983. Icebergs: their physical dimensions and the presentation and application of measured data. Annals of Glaciology 4:116-123.

JACKSON, G.D., and TAYLOR, F.G. 1972. Correlation of major Aphebian rock units in the northeastern Canadian Shield. Canadian Journal of Earth Sciences 9:1650-1669.

JOSENHANS, H.W., and BARRIE, J.V. 1982. Preliminary results of submersible observations on the Labrador Shelf. Geological Survey of Canada, Current Research, Part B:269-276.

KRANCK, K. 1964. Sediments of Exeter Bay, District of Franklin, In: Published Manuscript Report, Bedford Institute of Oceanography, No. 64-15. $60 \mathrm{p}$.

LEBLOND, P.H., OSBORN, T.R., HODGINS, D.O., GOODMAN, R., and METGE, M. 1981. Surface circulation in the western Labrador Sea. Deep Sea Research 28A:683-693.

LEWIS, C.F.M. 1978. The frequency and magnitude of drift-ice groundings from ice-scour tracks in the Canadian Beaufort Sea. In: Proceedings POAC
1977, Memorial University of Newfoundland, St. John's, Canada, September 1977. 568-579.

MACLEAN, B., and FALCONER, R.H.R. 1979. Iceberg scour abundance in Labrador Sea and Baffin Bay - a reconnaissance of regional variability. In: Proceedings of the First Canadian Conference on Marine Geotechnical Engineering, National Research Council Canada, Calgary, Alberta. 79-99.

LIEN, R. 1983. Iceberg scouring on the Norwegian continental shelf. 15th Offshore Technology Conference, Proceedings, Volume 3 (No. OTC 4585):41-48.

MACLEAN, B. 1985. Geology of the Baffin Island Shelf. In: Andrews, J.T., ed. Quaternary environments, eastern Canadian Arctic, Baffin Bay and west Greenland. London: George, Allen and Unwin Ltd. 154-177.

SRIVASTAVA, S.P., and HAWORTH, R.T. 1982. Bedrock structures off Cumberland Sound, Baffin Island Shelf: core sample and geophysical data. In: Embry, A.F., and Balkwill, M.R., eds. Arctic Geology and Geophysics. Canadian Society of Petroleum Geologists, Memoir 8:267-297.

MARKO, J.R., BIRCH, J.R., and WILSON, M.A. 1982. A study of long-term satellite-tracked iceberg drifts in Baffin Bay and Davis Strait. Arctic 35(1):234-240.

MCLAREN, P. 1982. The coastal geomorphology, sedimentology and processes of eastern Melville and western Byam Martin Islands, Canadian Arctic Archipelago. Geological Survey of Canada, Bulletin $333.39 \mathrm{p}$.

MCMILLAN, N.J. 1973. Surficial Geology of Labrador and Baffin Island shelves. In: Earth Science Symposium on Offshore Eastern Canada. Geological Survey of Canada, Paper 71-23:451-468.

MARLOWE, J.I. 1968. Unconsolidated marine sediments in Baffin Bay. Journal of Sedimentary Petrology 38(4):1065-1078.

PEREIRA, C.P.G. 1984. Determination of iceberg scoured sediment surfaces using quantitative microfaunal analysis. In: Abstracts, First Annual Mid-year Meeting, August 1984, San Jose, California. Tulsa, Oklahoma: Society of Economic Paleontologists and Mineralogists.

WOODWORTH-LYNAS, C.M.T, and BARRIE, J.V. 1984. Davis Strait Iceberg scouring analysis. C-CORE Technical Report No. 84-4. 78 p.

PRAEG, D.B. 1982. Seafloor relief - Baffin Island Shelf. Geological Survey of Canada, Open File Report No. 862.

MACLEAN, B., HARDY, I.A., and MUDIE, P.J. 1986. Quaternary Geology of the Southeast Baffin Island Shelf, N.W.T. Geological Survey of Canada, Paper 85-14. 38 p.

ROBE, R.Q., MAIER, D.C., and RUSSELL, W.E. 1980. Long term drift of icebergs in Baffin Bay and the Labrador Sea. Cold Regions Science and Technology 1:183-193.

U.S. NAVAL OCEANOGRAPHIC OFFICE. 1965 Oceanographic atlas of the North Atlantic Ocean. Section 1, tides and currents. Pub. No. 700.75 p.

VISHER, G.S. 1969. Grain size distributions and depositional processes. Journal of Sedimentary Petrology 39:1074-1106.

WELLS, D.E., and GRANT, S.T. 1981. An adaptable integrated navigation system: BIONAV. Proceedings of Colloquium III on Petroleum Mapping and Surveys in the 80's. Banff, Alberta: The Canadian Petroleum Associates.

WOODWORTH-LYNAS, C.M.T. 1983a. A possible submarine mud volcano from the southeast Baffin Island shelf. C-CORE Technical Report No. 83-2. $35 \mathrm{p}$.

$1983 \mathrm{~b}$. The relative age of ice scours using cross cutting relationships. C-CORE Technical Report No. 83-3. 54 p. 